Research article

\title{
Angiotensin II induced inflammation in the kidney and in the heart of double transgenic rats Juergen Theuer ${ }^{\dagger 1}$, Ralf Dechend ${ }^{\dagger 1}$, Dominik N Muller ${ }^{\dagger 1}$, Joon-Keun Park ${ }^{2}$, Anette Fiebeler ${ }^{2}$, Peter Barta1, Detlev Ganten1, Hermann Haller², Rainer Dietz ${ }^{1}$ and Friedrich C Luft*1
}

\author{
Address: ${ }^{1}$ Franz Volhard Clinic, Charite' and Max Delbrück Center for Molecular Medicine, Berlin, Humboldt University of Berlin, Germany and \\ ${ }^{2}$ Medical University of Hannover, Dept. of Nephrology, Hanover, Germany \\ E-mail: Juergen Theuer - theuer@fvk-berlin.de; Ralf Dechend - dechend@fvk-berlin.de; Dominik N Muller - muller@fvk-berlin.de; Joon- \\ Keun Park - park@fvk-berlin.de; Anette Fiebeler - fiebeler@fvk-berlin.de; Peter Barta - barpeti@hotmail.com; Detlev Ganten - luft@fvk- \\ berlin.de; Hermann Haller - haller@fvk-berlin.de; Rainer Dietz - dietz@fvk-berlin.de; Friedrich C Luft* - luft@fvk-berlin.de \\ *Corresponding author tContributed equally
}

This article is available from: http://www.biomedcentral.com//47I-226I/2/3

(C) 2002 Theuer et al; licensee BioMed Central Ltd. Verbatim copying and redistribution of this article are permitted in any medium for any purpose, provided this notice is preserved along with the article's original URL.

\begin{abstract}
Background: We are investigating a double transgenic rat (dTGR) model, in which rats transgenic for the human angiotensinogen and renin genes are crossed. These rats develop moderately severe hypertension but die of end-organ cardiac and renal damage by week 7 . The heart shows necrosis and fibrosis, whereas the kidneys resemble the hemolytic-uremic syndrome vasculopathy. Surface adhesion molecules (ICAM-I and VCAM-I) are expressed early on the endothelium, while the corresponding ligands are found on circulating leukocytes. Leukocyte infiltration in the vascular wall accompanies PAI-I, MCP-I, iNOS and Tissue Factor expression. Furthermore we show evidence that Ang II causes the upregulation of NF-kB in our model.

Methods: We started PDTC-treatment on four weeks old dTGR (200 mg/kg sc) and age-matched $S D$ rats.. Blood-pressure- and albuminuria- measurements were monitored during the treatement period (four weeks). The seven weeks old animals were killed, hearts and kidneys were isolated and used for immunohistochemical-and electromobility shift assay analsis.

Results: Chronic treatment with the antioxidant PDTC decreased blood pressure ( $162 \pm 8$ vs. 190 $\pm 7 \mathrm{~mm} \mathrm{Hg}, \mathrm{p}=0.02)$. Cardiac hypertrophy index was significantly reduced $(4.90 \pm 0.1$ vs. $5.77 \pm$ $0.1 \mathrm{mg} / \mathrm{g}, \mathrm{p}<0.00 \mathrm{I})$ compared to dTGR. PDTC reduced $24 \mathrm{~h}$ albuminuria by $85 \%(2.7 \pm 0.5 \mathrm{vs}$. $18.0 \pm 3.4 \mathrm{mg} / \mathrm{d}, \mathrm{p}<0.00 \mathrm{I}$ ) and prevented death significantly. Vascular injury was ameliorated in small renal and cardiac vessels. PDTC inhibited NF-KB binding activity in heart and kidney. Immunohistochemical analysis shows increased expression of the $\mathrm{p} 65 \mathrm{NF}-\mathrm{KB}$ subunit in the endothelium, smooth muscles cells of damaged small vessels, infiltrated cells, glomeruli, tubuli and collecting ducts of dTGR. PDTC markedly reduced the immunoreactivity of p65.
\end{abstract}

Conclusion: Our data show that inhibition of NF-KB by PDTC markedly reduces inflammation, iNOS expression in the dTGR most likely leading to decreased cytotoxicity, and cell proliferation. Thus, NF-KB activation plays an important role in ANG II-induced end-organ damage. 


\section{Introduction}

Hypertension injures blood vessels and thereby causes end-organ damage. The mechanisms are complicated and, although studied for decades in experimental animal models, are only currently being elucidated [1] The endothelial layer acts as a signal transduction interface for hemo-dynamic forces in the regulation of vascular tone and chronic structural remodeling of arteries. Effects of mechanical forces on signal transduction and gene expression in endothelial cells have been demonstrated [2]. Microvascular endothelium in hypertensive animals has been shown to exhibit increased oxyradical production attributable to xanthine oxidase [3]. Oxyradical production by endothelial cells can result in leukocyte-endothelial adhesion responses that involve transcription-independent and -dependent surface expression of different endothelial cell adhesion molecules. Infiltration of the permeabilized endothelium by leukocytes sets the stage for an inflammatory cascade, involving cytokines, chemokines, growth factors, and matrix metalloproteinases. Altered integrin signaling, the production of tenacin, epidermal growth factor signaling, tyrosine phosphorylation, and activation of downstream pathways culminate in vascular smooth muscle cell proliferation. [4-6] Evidence is accumulating that matrix molecules provide an environment which decreases the rate of programmed cell death.

We have studied a double-transgenic rat model. The rats harbor both the human renin and human angiotensinogen genes $[7,8]$. The rat and human renin-angiotensin systems do not interact, so the hypertension and vasculopathy exhibited by these rats is the result of the overexpression of the human renin-angiotensin system. The rats were developed for the expressed purpose of studying human renin inhibitors that ordinarily do not function in rats. However, we have found that this model, which features renal and cardiac failure by 8 weeks of age in these animals, also provides great utility in studying blood pressure-independent Ang II-related effects. To exclude possible effects of blood pressure, we lowered blood pressure with non-angiotensin-related hypotensive agents. This strategy delayed morbidity and mortality by 1 week but did not ameliorate the inflammatory disease process.

Many inflammation-mediating genes are activated by the transcription factor NF- $\mathrm{kB}$, which resides inactive and bound to the inhibitory protein I- $\mathrm{\kappa B}$ in the cytoplasm of $\mathrm{T}$ lymphocytes, monocytes, macrophages, endothelial cells, and smooth muscle cells [9]. ANG II stimulates NADPH oxidase, which generates reactive oxygen species (ROS) [10]. ROS may act as signal transduction messengers for several important transcription factors, including NF-KB and AP-1 [11]. Several reports have indicated that angiotensin converting enzyme (ACE) inhibition decreased NF-אB in renal disease $[12,13]$.

In vitro and in vivo studies showed that pyrrolidine dithiocarbamate (PDTC) is a potent inhibitor of NF- $\mathrm{KB}$, but had no effect on AP-1, CREB, Sp-1, and octamer-binding proteins $[14,15]$. The precise mechanism for the biological effects of PDTC is still controversial. Several studies have reported that metal-chelating, thiol modifying and oxygen radical-scavenging antioxidative properties mediate the inhibition of NF-KB [15]. We recently observed that rats harboring both human renin and angiotensinogen genes (dTGR) develop severe renal and cardiac damage, accompanied by increased NF-KB DNA binding activity, MCP-1 production, adhesion molecule expression, inflammation, and die by seven weeks of age $[16,17]$. We now investigated the hypothesis that PDTC inhibition of NF- $\mathrm{KB}$ prevents inflammation and ameliorates cardiac and renal damage.

\section{Material and Methods Study design}

Experiments were conducted in 4 week-old male dTGR and age-matched SD rats. The dTGR line and characteristics are described elsewhere ${ }^{1}$. The rats were purchased from RCC (Füllinsdorf, CH), kept in rooms at $24 \pm 2^{\circ} \mathrm{C}$, were fed with a standard rat diet containing $0.2 \%$ sodium by weight, and were allowed free access to tap water. All procedures were done according to guidelines from the American Physiological Society and were approved by local authorities (permit \# G 408/97). In the first part of the study we investigated 15 untreated dTGR and compared them to 15 Sprague Dawley (SD) rats in the second part of the study fifteen dTGR received PDTC (Sigma, Germany) for 3 weeks once a day (200 mg/kg s.c.) $[18,19]$, while 15 dTGR and 15 Sprague Dawley (SD) rats received vehicle $(0.9 \% \mathrm{NaCl})$. Systolic blood pressure was measured weekly by tail-cuff under light ether anesthesia $20 \mathrm{~h}$ after the last drug dose. Urine samples were collected over a 24 $\mathrm{h}$ period. Urinary rat albumin was measured with a commercially available ELISA (Celltrend, Germany). Rats were killed at age 7 weeks. The kidneys and hearts were washed with ice cold saline, blotted dry, and weighed. For electrophoretic mobility shift assay (EMSA) of NF-kB and AP-1, the tissues were snap-frozen in liquid nitrogen, for immunohistochemistry in isopentane $\left(-35^{\circ} \mathrm{C}\right)$, and stored at $80^{\circ} \mathrm{C}$.

\section{Immunohistochemistry}

Frozen kidneys and hearts were cryosectioned at $6 \mu \mathrm{m}$ thickness and air dried as described earlier $[20,21]$. The sections were fixed with cold acetone, washed with TBS, and incubated for $60 \mathrm{~min}$ in a humid chamber at room temperature with primary monoclonal antibodies against rat monocytes/macrophages (ED1, Serotec, England), NF- 


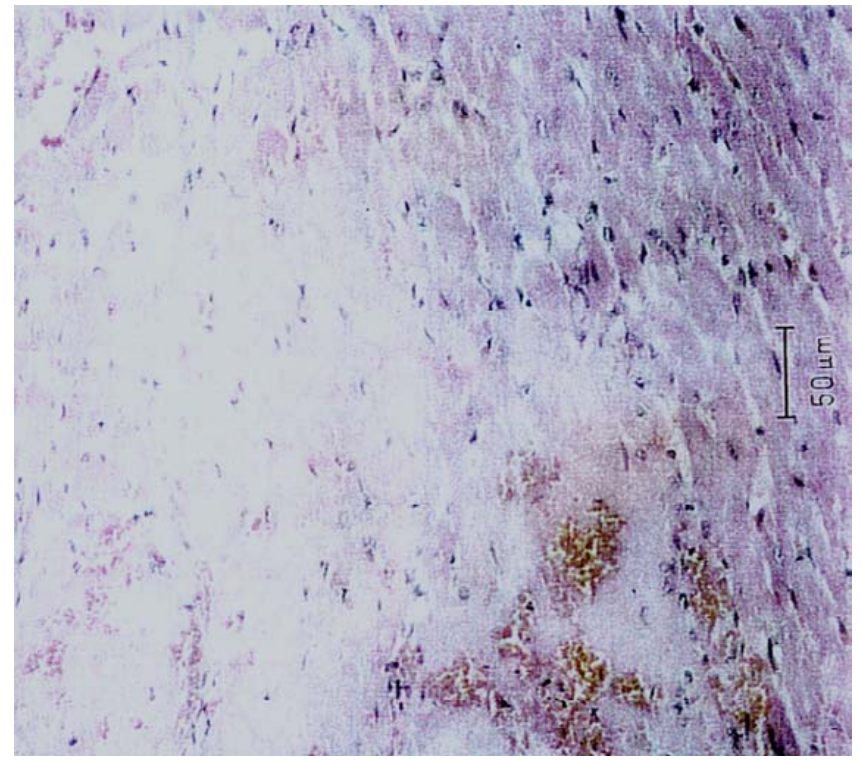

\section{Figure I}

Section from dTGR kidney stained with hematoxylin/eosin and periodic acid-Schiff-stained section. Small vessels showed increased intimal and medial thickness as well as hyaline deposits, tubuls were swollen and filled with proteinaceous material.

KB subunit p65 (Roche Boehringer, Germany), ICAM-1, VCAM-1, LFA-4, VLA-1 (1A29, R\&D Systems, England) and polyclonal inducible NO synthase (iNOS/NOS2) (ABR, USA). After washing with TBS, the sections were incubated with a bridging antibody (rabbit-anti-mouse IgG; Dako, Germany) for $30 \mathrm{~min}$ at room temperature and washed again with TBS. The APAAP-complex (Dako, Germany) was applied and the sections were incubated for 30 min at room temperature. The immunoreactivity was visualized by development in a mixture of naphthol-AS-BIphosphate (Sigma, Germany) with neufuchsin (Merck, Germany). Endogenous alkaline phosphatase was blocked by addition of $10 \mathrm{mmol} / \mathrm{L}$ levamisole (Sigma, Germany) to the substrate solution. The sections were slightly counter stained in Mayer's haemalaun (Merck, Germany), blued in a tap water, and mounted with GelTol (Coulterimmunotech, Germany). Immunostaining was performed as described earlier. Semiquantitative scoring of ED-1 positive cells was performed using computerized cell count program (KS 300 3.0, Zeiss, Germany). Fifteen different areas of each heart and kidney samples ( $n=5$ in all groups) were analyzed. The samples were examined without knowledge of the rats' identity.

\section{Electrophoretic mobility shift assay (EMSA)}

Tissue extracts and EMSA for the transcription factor NF$\mathrm{KB}$ were performed as described earlier $[22,23]$. Briefly, frozen total kidneys were pulverized in liquid nitrogen

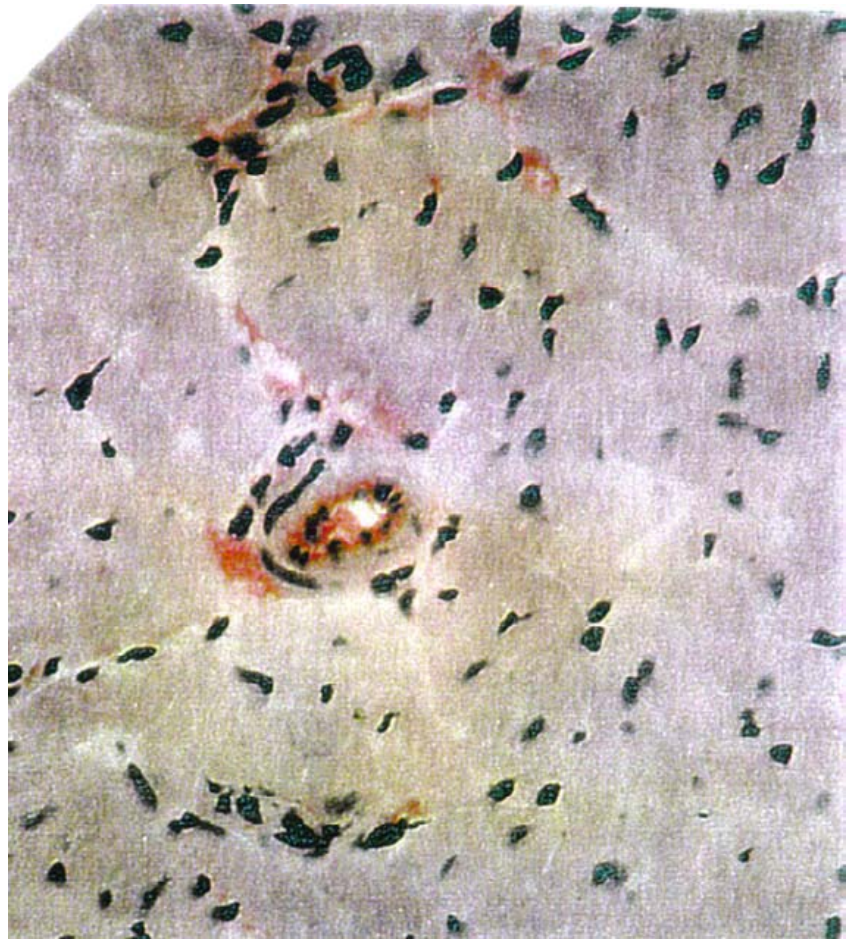

Figure 2

Section from dTGR kidney stained with hematoxylin/eosin and periodic acid-Schiff-stained section. Small vessels showed increased intimal and medial thickness as well as hyaline deposits, tubuls were swollen and filled with proteinaceous material.

with a pestle and mortar, and resuspended in $3 \mathrm{~mL} 50$ $\mathrm{mmol} / \mathrm{l}$ Tris ( $\mathrm{pH}$ 7.4) containing a complete inhibitor tablet (Roche Boehringer, Germany) and $1 \mathrm{mmol} / \mathrm{l} \mathrm{Na-ortho-}$ vanadate (Sigma Chemie, Germany). The suspension was centrifuged $\left(4000 \mathrm{~g}, 4 \mathrm{~min}, 4^{\circ} \mathrm{C}\right)$. The pellet was resuspended and lysed for $30 \mathrm{~min}$ in whole cell lysate buffer (20 mmol/l Hepes pH 7.9, $350 \mathrm{mmol} / \mathrm{l} \mathrm{NaCl}, 20 \%$ glycerol, $1 \mathrm{mmol} / \mathrm{l} \mathrm{MgCl} 2,0.5 \mathrm{mmol} / \mathrm{l}$ EDTA, $0.1 \mathrm{mmol} / \mathrm{l} \mathrm{EG-}$ $\mathrm{TA}$, and $1 \% \mathrm{NP}-40)$ and again centrifuged $(13000 \mathrm{~g}, 10$ $\min , 4^{\circ} \mathrm{C}$ ). The supernatant was aliquoted and frozen in liquid nitrogen at $-80^{\circ} \mathrm{C}$ until use. The protein concentration for EMSA and Western blot was quantified by the Bradford method. For EMSA, total renal homogenates (50 $\mu \mathrm{g})$ were incubated in binding reaction medium $(2 \mu \mathrm{g}$ poly dI-dC, $1 \mu \mathrm{g} \mathrm{BSA}, 1 \mathrm{mmol} / \mathrm{l} \mathrm{DTT}, 20 \mathrm{mmol} / \mathrm{l}$ Hepes $\mathrm{pH} 8.4,60 \mathrm{mmol} / \mathrm{l} \mathrm{KCl}$ and $8 \%$ Ficoll) with $0.5 \mathrm{ng}$ of 32PdATP end-labeled oligonucleotide, containing the NF- $\mathrm{\kappa B}$ binding site from the MHC-enhancer $\left(\mathrm{H} 2 \mathrm{~K}, 5^{5}\right.$-gatcCAGGGCTGGGGATTCCCCATCTCCACAGG) at $30^{\circ} \mathrm{C}$ for 30 min. In competition assays 50 or $100 \mathrm{ng}$ unlabeled H2K oligonucleotides were used. For supershift assay, $1 \mu \mathrm{g}$ of anti-p50, anti-p65, anti-Rel B, and anti-c-Rel was added $20 \mathrm{~min}$ to the homogenates before addition of the labeled probe. For AP-1 double-stranded oligonucleotides con- 


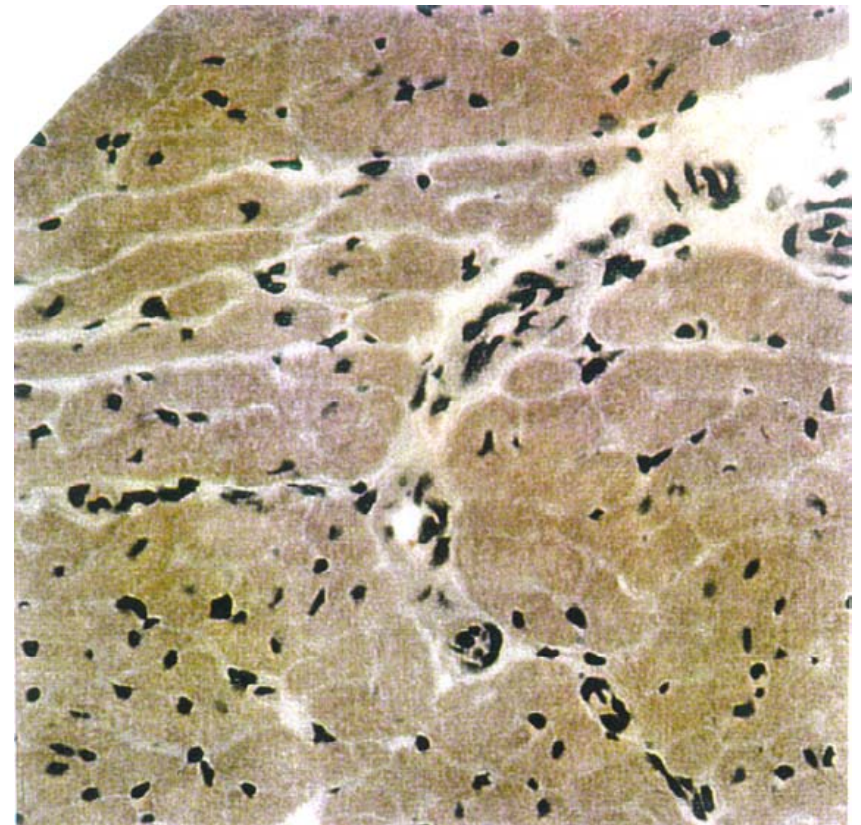

Figure 3

Representative immunohistochemical photomicrograph of PAI-I and Fibronectin in the heart of dTGR. PAI-I and fibronectin expression were increased in the perivascular space and adventitia of dTGR compared to SD.

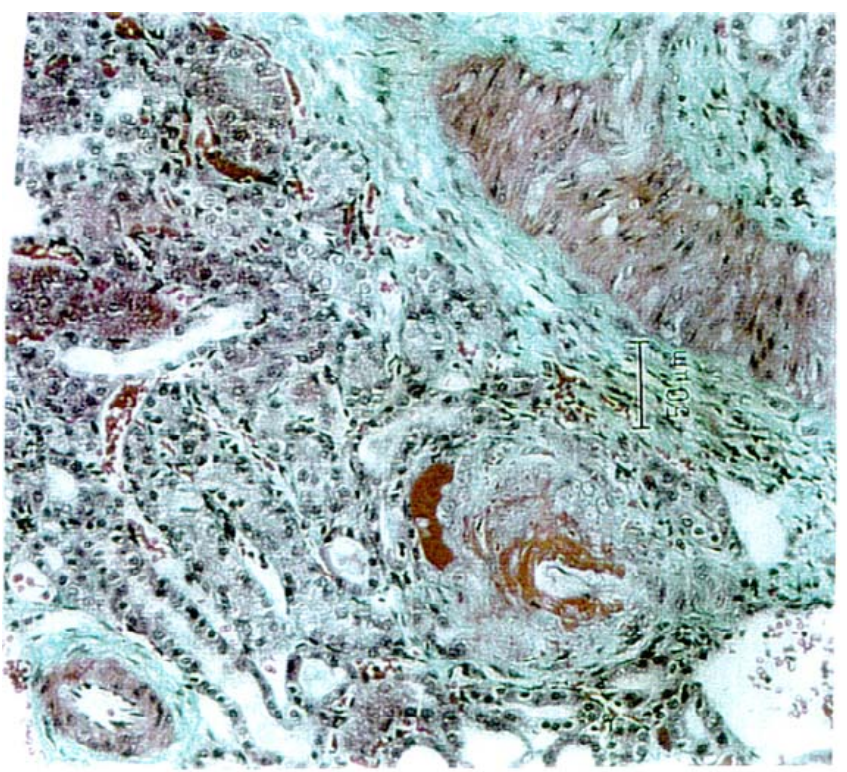

\section{dTGR}

Figure 4

Representative immunohistochemical photomicrograph of PAI-I and Fibronectin in the heart of dTGR. PAI-I and fibronectin expression were increased in the perivascular space and adventitia of dTGR compared to SD.

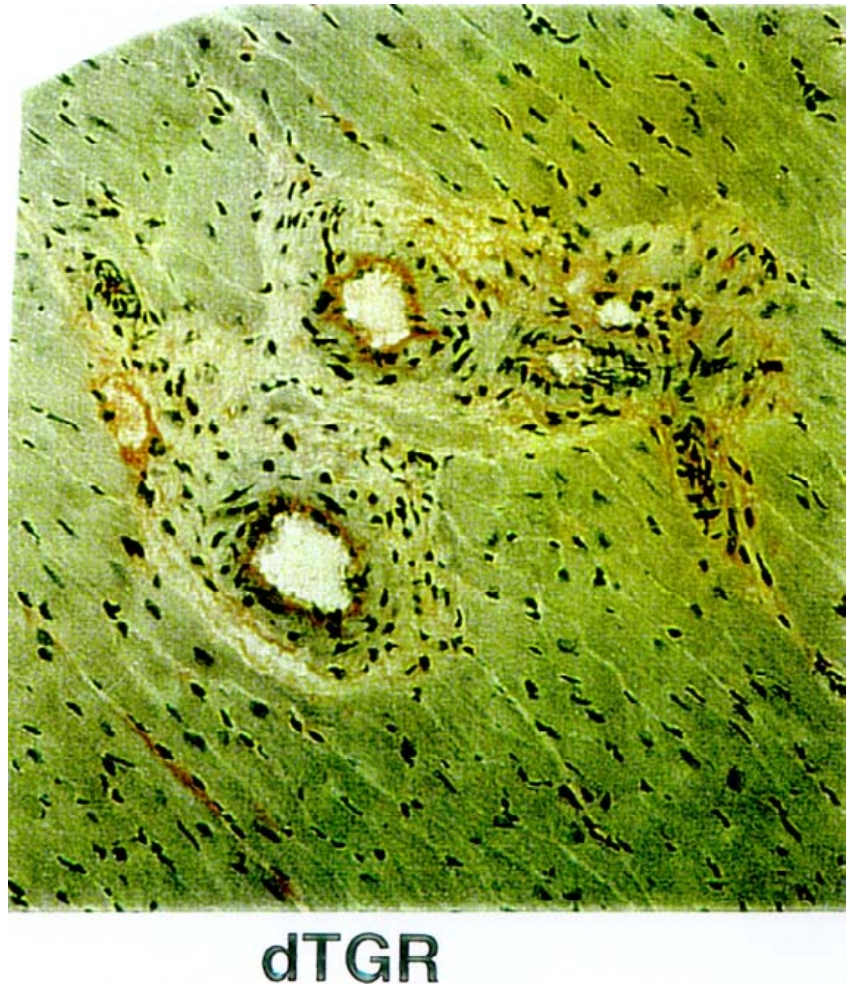

Figure 5

Representative immunohistochemical photomicrograph of PAI-I and Fibronectin in the heart of dTGR.

taining the consensus sequence for AP1 (Santa Cruz, USA., 5'-GAT CGA ACT GAC CGC CCG CCG CCC GT-3') were radiolabeled with $\gamma-32 \mathrm{P}$ with the use of T4 polynucleotide kinase by standard methods and purified over a column. The DNA-protein complexes were analyzed on a $5 \%$ polyacrylamide gel 0,5\% Tris buffer, dried and autoradiographed. In competition assays $50 \mathrm{ng}$ unlabeled $\mathrm{H} 2 \mathrm{~K}$ or AP-1 oligonucleotides were used.

\section{Statistical analysis}

Data are presented as means \pm SEM. Statistically significant differences in mean values were tested by ANOVA and the Tukey's multiple range test. A value of $\mathrm{p}<0.05$ was considered statistically significant. The data were analyzed using SYSTAT $^{\circledR}$ statistical software (SYSTAT Inc, Evanston, IL, USA).

\section{Results}

DTGR feature hypertension $(190 \pm 7 \mathrm{~mm} \mathrm{Hg}$ vs $107 \pm 2$ $\mathrm{mm} \mathrm{Hg}$ for SD at week $7, \mathrm{p}<0.001 \mathrm{n}=15$, severe renal damage, and focal necrosis in heart and kidney and a mortality of $40 \%$ at 7 weeks. Cardiac hypertrophy is one of the leading features in dTGR (5,9 vs 3,6 heart weigth/body weigth (mg/g). $24 \mathrm{~h}$ albuminuria progressively increased in untreated dTGR from 5 to 7 weeks. ( $57.1 \pm 8.7$ vs. $0.3 \pm$ 


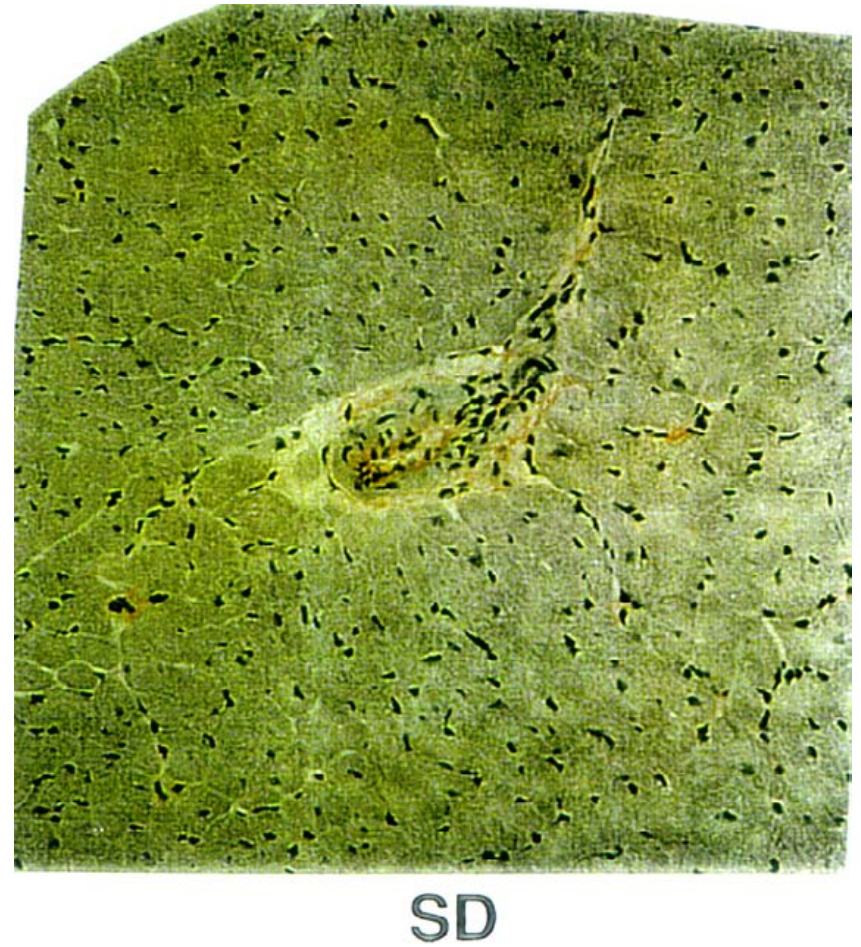

Figure 6

Representative immunohistochemical photomicrograph of PAI-I and Fibronectin in the heart of SD.

$0.1 \mathrm{mg} / \mathrm{d}$ week 7). Small vessels showed increased intimal and medial thickness as well as hyaline deposits, tubuls were swollen and filled with proteinaceous material (Fig. 1 and 2). PAI-1 and fibronectin expression were increased in the perivascular space and adventitia of dTGR compared to SD (Fig. 3,4,5,6).

There was significant infiltration in cardiac and renal perivascular space of dTGR compared to SD. Fig. 7 and 8 show a representative immunohistochemistry for ED1, a marker for macophages in the heart and in the kidney ( 9 and 10). Fig. 24 shows semiquantative scoring for macrophage-monocyte-infiltration of ED-1 in the kidney and in the heart. This was perforned using a computerized cell count programm.

The expression ot the adhesion protein VCAM-1 was increased in the interstitium, intima and adventitia of the small renal and cardiac vessels in dTGR compared to SD animals (Fig. 11,12,13,14). Similar results were obtained for ICAM-1 (see below). The counterreceptors for ICAM-1 and VCAM-1, $\alpha$ L $\beta 2$ integrin (LFA-1) and $\alpha 4 \beta 1$ (VLA-4) were upregulated in the perivascular space and the adventitia of the heart (Fig. 15 and 16) and the kidney (Fig. 17 and 18) in dTGR compared to SD.

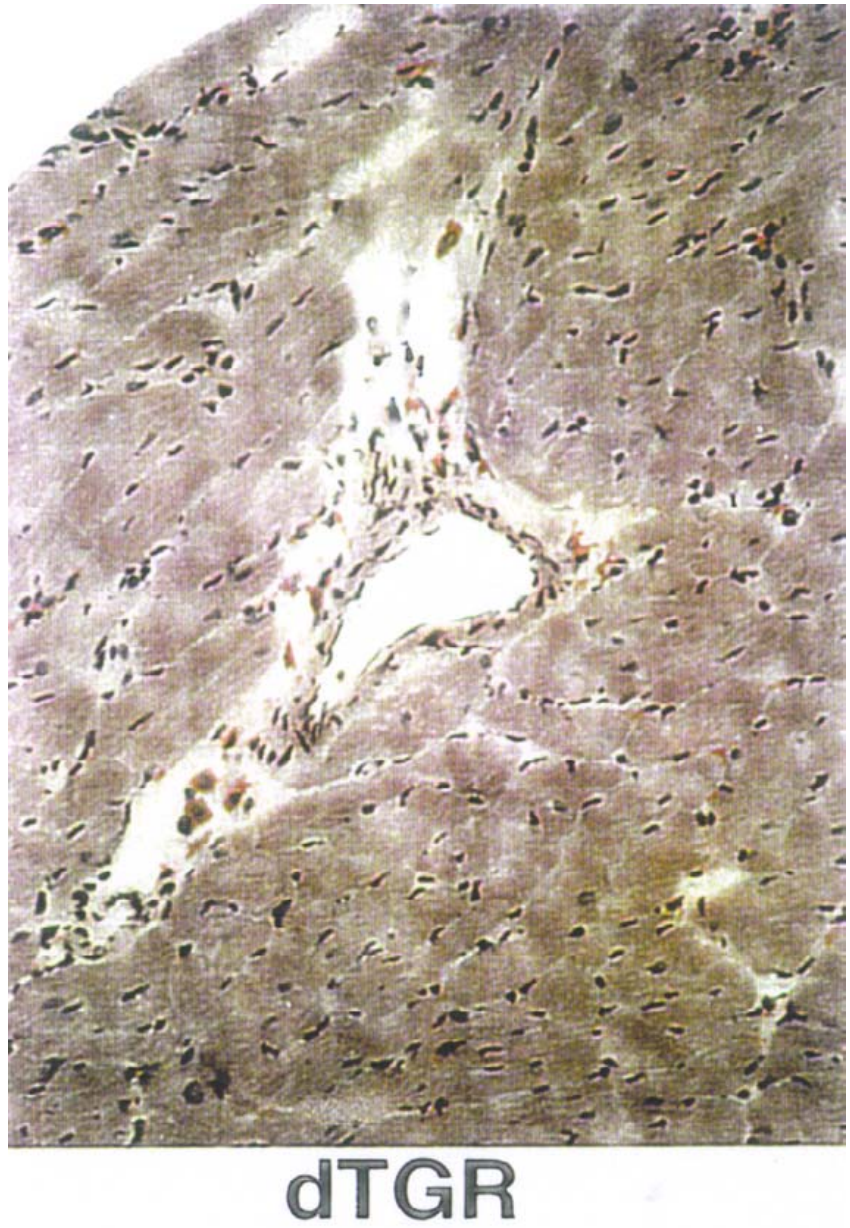

Figure 7

Representative immunohistochemical photomicrograph of $E D-I$ in the heart of $d T G R$.

A schematic diagram in Fig. 19 summarizes the Ang II signaling in the dTGR model, resulting in oxidative stress, participation of endothelin, and transcription factor activation. These transcription factors activate a host of genes involved in inflammation including surface adhesion molecules, thrombogenic factors, chemokines, and inducible NO synthase

Subsequently, we used the dTGR model for a pharmacological intervention with PDTC to prevent NF- $\kappa \mathrm{B}$ signalling. In week 7 mortality was reduced to $0 \%$, cardiac hypertrophy reduced to $4.90 \pm 0.1$ (vs. $5.77 \pm 0.1 \mathrm{mg} / \mathrm{g}$, p $<0.001$ ), albuminuria to $2.5 \pm 0.8 \mathrm{mg} / \mathrm{d}$ and blood pressure to $162 \pm 8 \mathrm{~mm} \mathrm{Hg}$, respectively. ICAM-1 expression in the kidney was increased in the intima, adventitia, and in the perivascular space of the small vessels in untreated dTGR. Glomeruli and tubules also showed increased ICAM-1 expression. Expression of ICAM-1 was markedly reduced by treatment with PDTC and was similar to the 


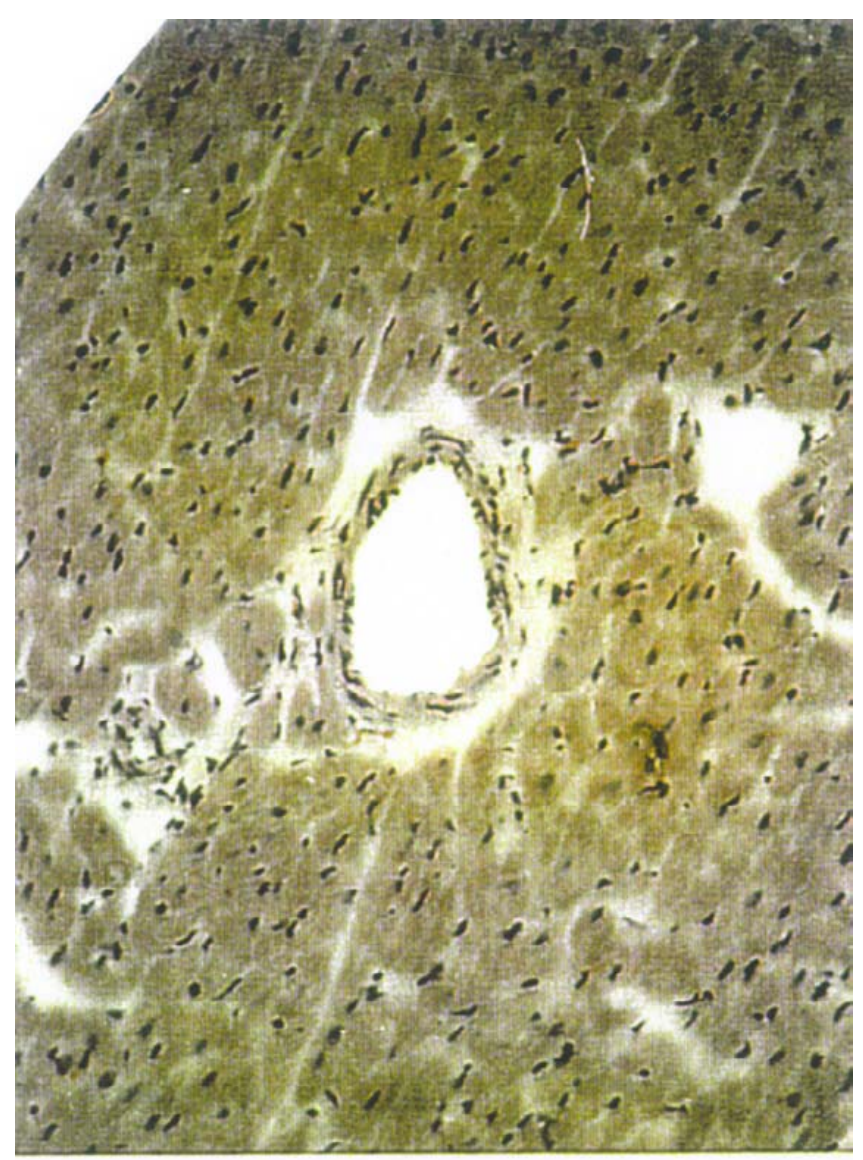

SD

Figure 8

Representative immunohistochemical photomicrograph of ED-I in the heart of SD animals.

constitutive ICAM-1 expression in control animals at week 7 (Fig. 20a,b,c). Furthermore we showed significantly reduced macrophage-monocyte-infiltration in the kidney and in the heart by semiquantative cell count analysis (Fig. 24) in PDTC treated rats compared to untreated dTGR ( $6 \pm 1$ vs. $22 \pm 1, \mathrm{p}<0.0001)$. These results demonstrate that PDTC treatment reduced mononuclear cell infiltration and inhibited the expression of adhesion molecules.

Next, we investigated the effects of PDTC on iNOS expression. We observed a strong increase in iNOS expression in the glomeruli in the vessel walls of renal arterioles (Fig. $21 \mathrm{~d}, \mathrm{e}, \mathrm{f})$. Treatment with PDTC greatly reduced the iNOS immunoreactivity both in the blood vessels and the glomeruli. Furthermore, we investigated the activation of the transcription factor NF- $\mathrm{KB}$, which is one of the main regulator of ICAM-1 and iNOS gene expression. Immunohistochemistry (phase contrast resolution) shows the lo-

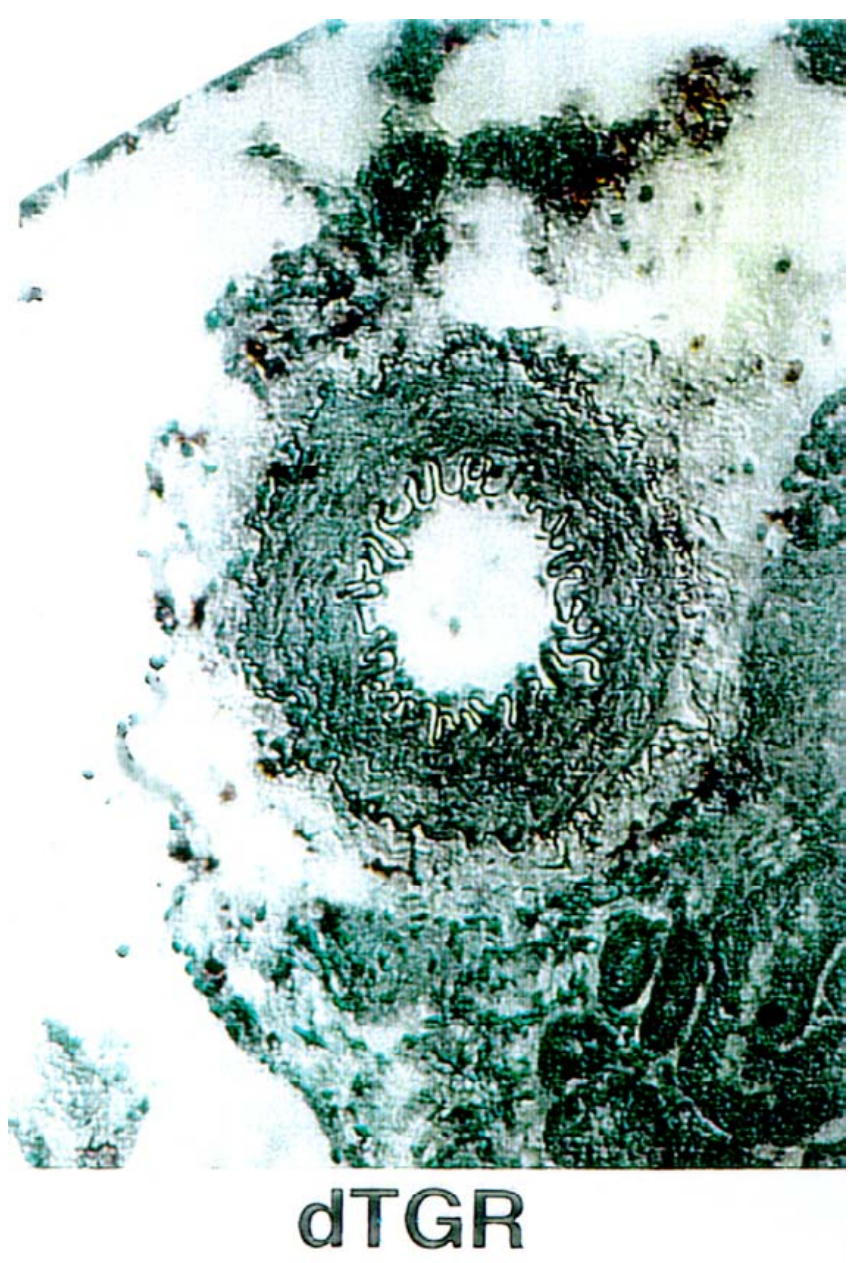

Figure 9

Representative immunohistochemical photomicrograph of ED-I in the kidney of dTGR.

calization of the subunit p 65 of NF- $\kappa \mathrm{B}$ in a cardiac vessel. The p65 expression was increased in the endothelium, smooth muscle cells (Fig. 22), as well as in the vessel wall, infiltrated cells, glomeruli, and tubules (data not shown) of dTGR kidneys. PDTC markedly reduced p65 expression (Fig. 22). No immunoreaction was observed in non-transgenic SD rats (Fig. 22). The antibody recognizes an epitope overlapping the nuclear location signal of p65 subunit and therefore selectively stains released, activated

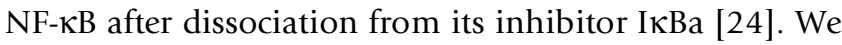
used EMSA for the detection of NF- $\kappa B$ DNA binding activity in the kidney (Fig. 23A) and heart (Fig. 23D). NF-кB DNA binding activity in the kidney was markedly reduced by PDTC treatment and even more in the heart. Each lane represents a separate animal. Renal homogenates were incubated with antibodies against the NF- $\mathrm{B}$ subunits antip50, anti-p65, anti-c-Rel, and anti-Rel B (23 B). Binding specificity was demonstrated by competition of excess un- 


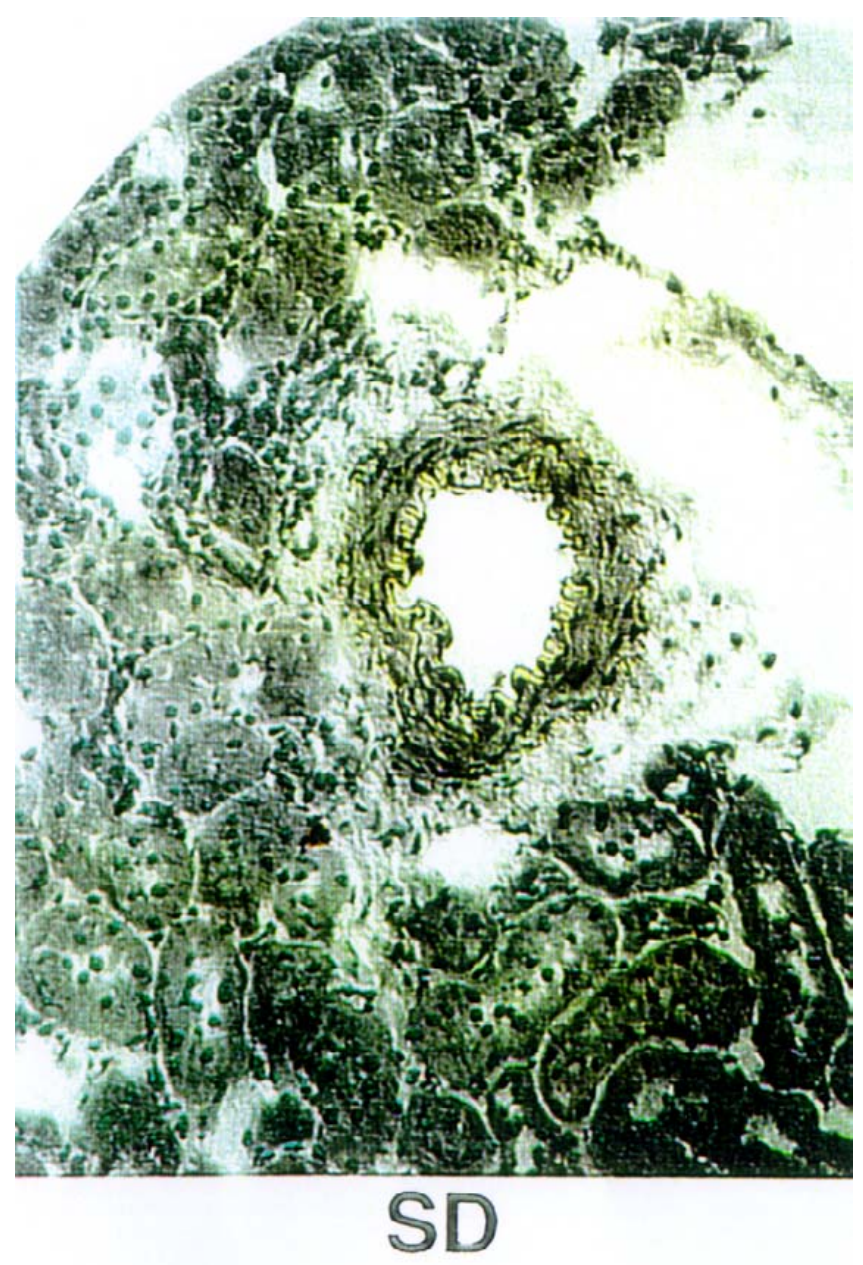

Figure I 0

Representative immunohistochemical photomicrograph of ED-I in the kidney of SD animals.

labeled oligonucleotides containing the $\mathrm{kB}$ site from the MHC-enhancer (H2K) (23 C). AP-1 activity was increased in dTGR kidneys compared with SD (data not shown). However, PDTC treatment did not reduce AP-1 binding activity (data not shown).

\section{Discussion}

As the growing role of "oxidative stress" in the pathogenesis of hypertension becomes more appreciated, our impression of hypertension as a rather indolent, solely hemo-dynamic process is being revised [25]. Reactive oxygen species are the end result of univalent reductions in oxygen, resulting in the production of superoxide anion, hydrogen peroxide, and water. Reactive oxygen species influence both normal and abnormal cellular processes, including cellular growth, hypertrophy, remodeling, lipid oxidation, modulation of vascular tone, and inflammation [26]. Reactive oxygen species can also act as intracel-

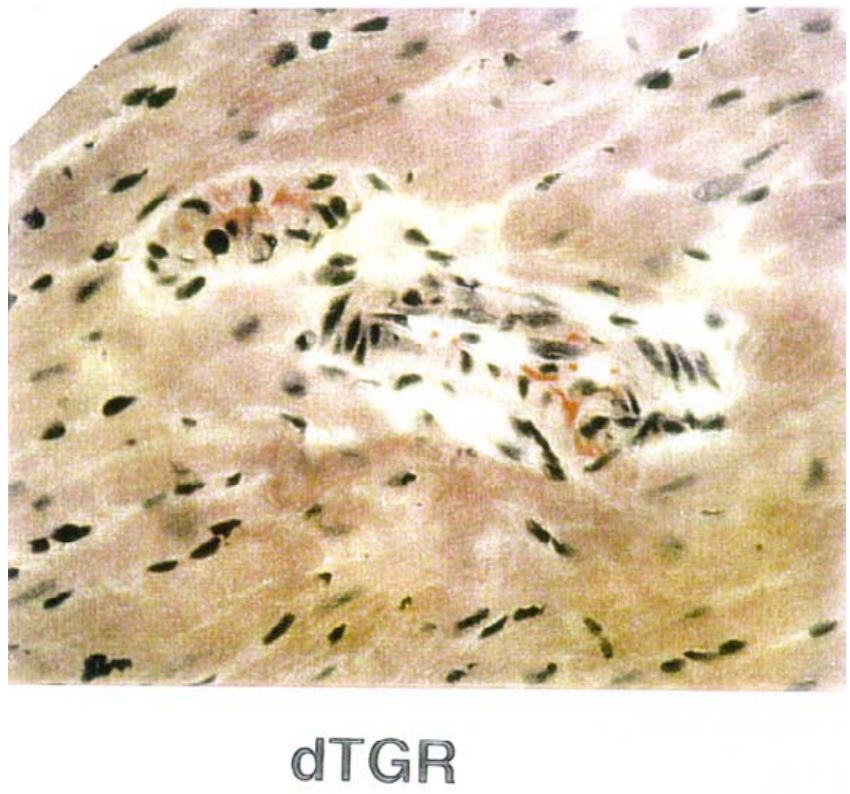

Figure I I

Representative immunohistochemical photomicrograph of VCAM-I in the heart of dTGR.

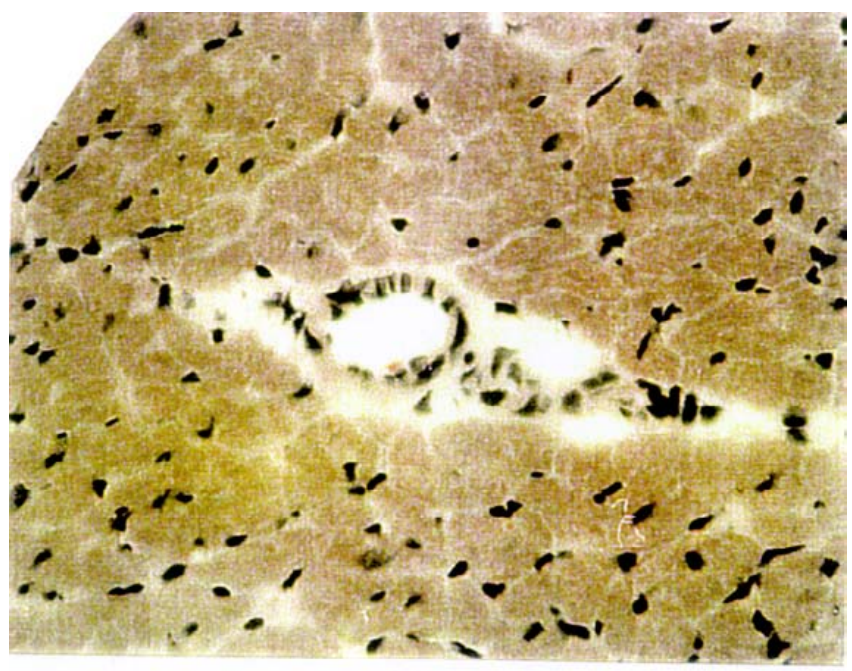

SD

Figure 12

Representative immunohistochemical photomicrograph of VCAM-I in the heart of SD animals.

lular signaling molecules in vascular cells controlling growth, survival, and apoptosis [4]. An important source of reactive-oxygen species are the NADH/NADPH oxidases, which are regulated in part by Ang II [10]. Touyz and Schiffrin recently showed that in vascular smooth muscle cells from human peripheral resistance arteries, Ang II in- 


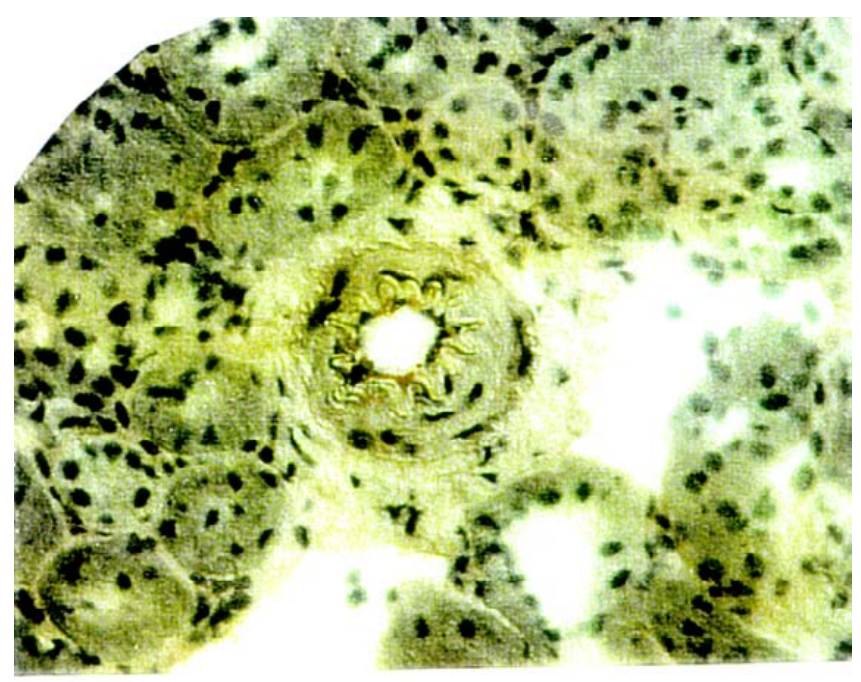

\section{dTGR}

Figure 13

Representative immunohistochemical photomicrograph of VCAM-I in the kidney of dTGR.

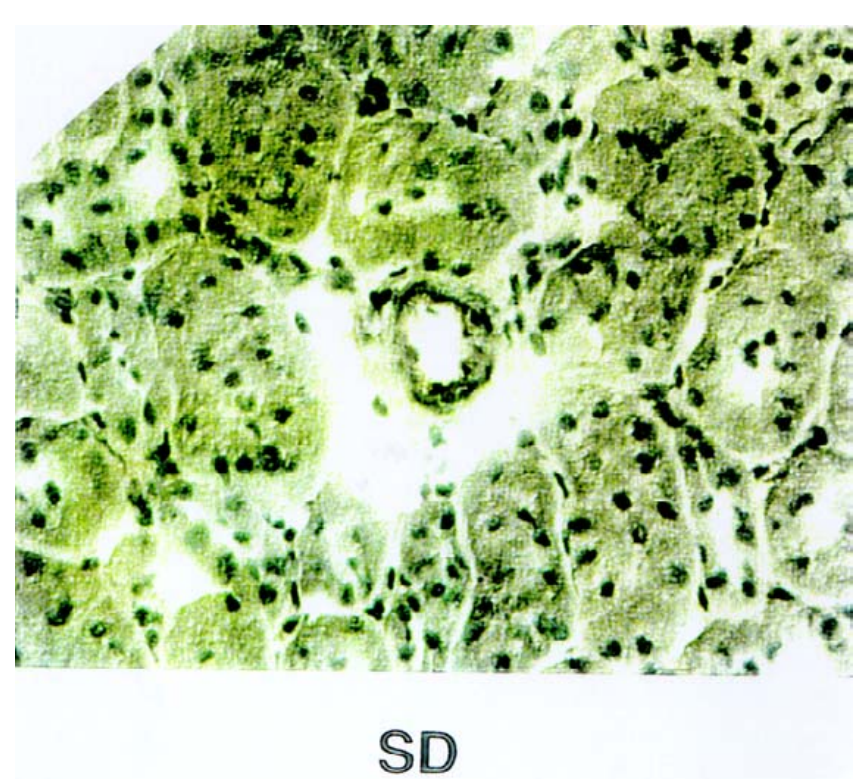

Figure I4

Representative immunohistochemical photomicrograph of VCAM-I in the kidney of SD animals.

creased $\mathrm{H}_{2} \mathrm{O}_{2}$ generation through phospholipase D-dependent, NADH/NADPH oxidase-sensitive pathways [27]. A role for reactive oxygen species in Ang II-mediated transcription factor activation has been established. The potential targets of reactive oxygen species in endothelial and vascular smooth muscle cells are extracellular signalrelated kinases, stress-activated protein kinases, caspases,

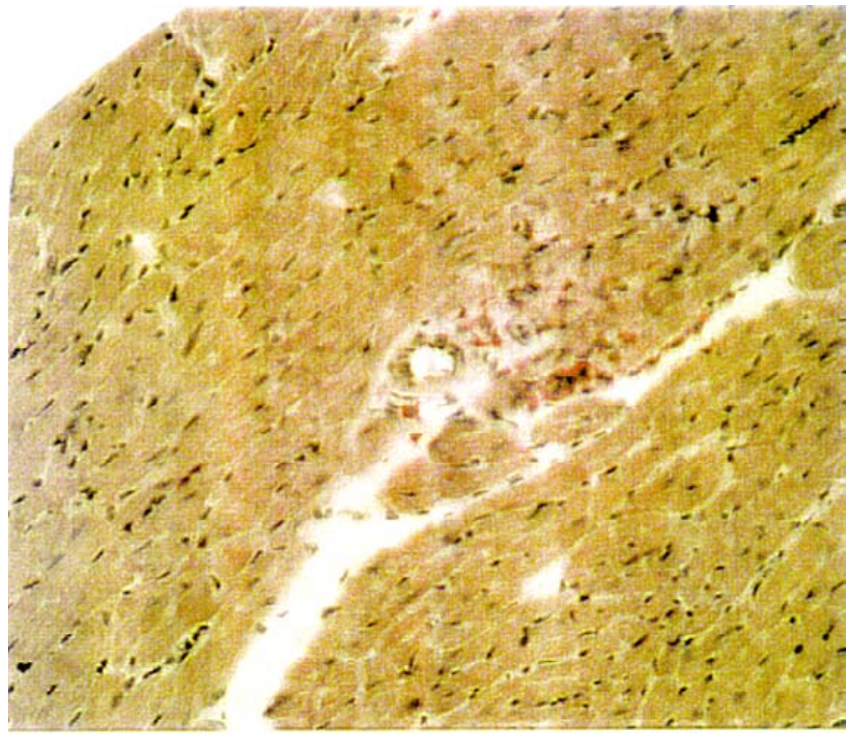

LFA-1

Figure 15

Representative immunohistochemical photomicrograph of LFA-I in the heart of dTGR.

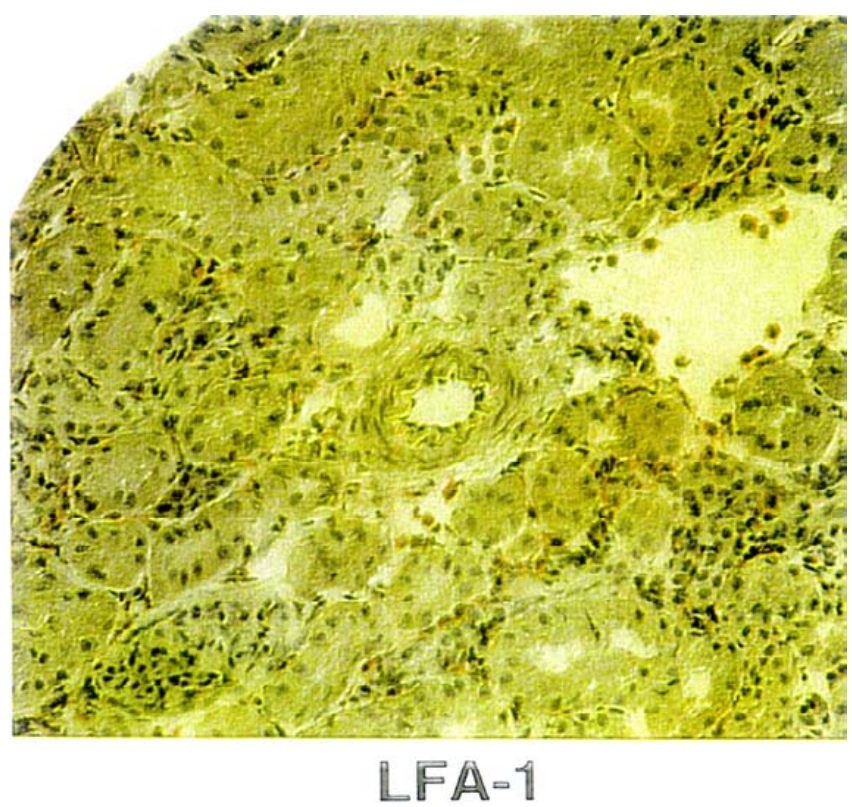

Figure 16

Representative immunohistochemical photomicrograph of LFA-I in the heart of SD animals.

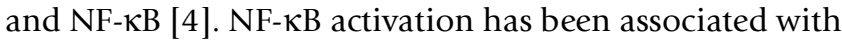
vascular inflammation [28]. The activation of NF- $\mathrm{KB}$ involves the phosphorylation and subsequent proteolytic

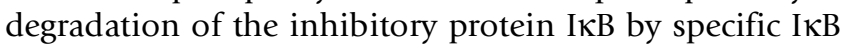




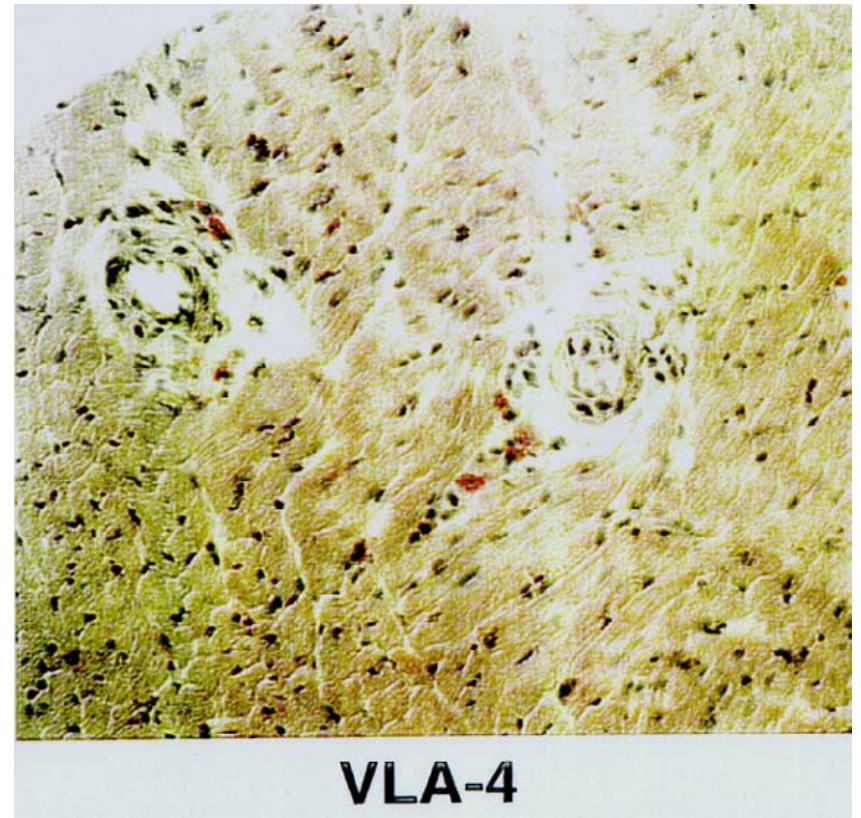

Figure 17

Representative immunohistochemical photomicrograph of VLA-4 in the kidney of dTGR.

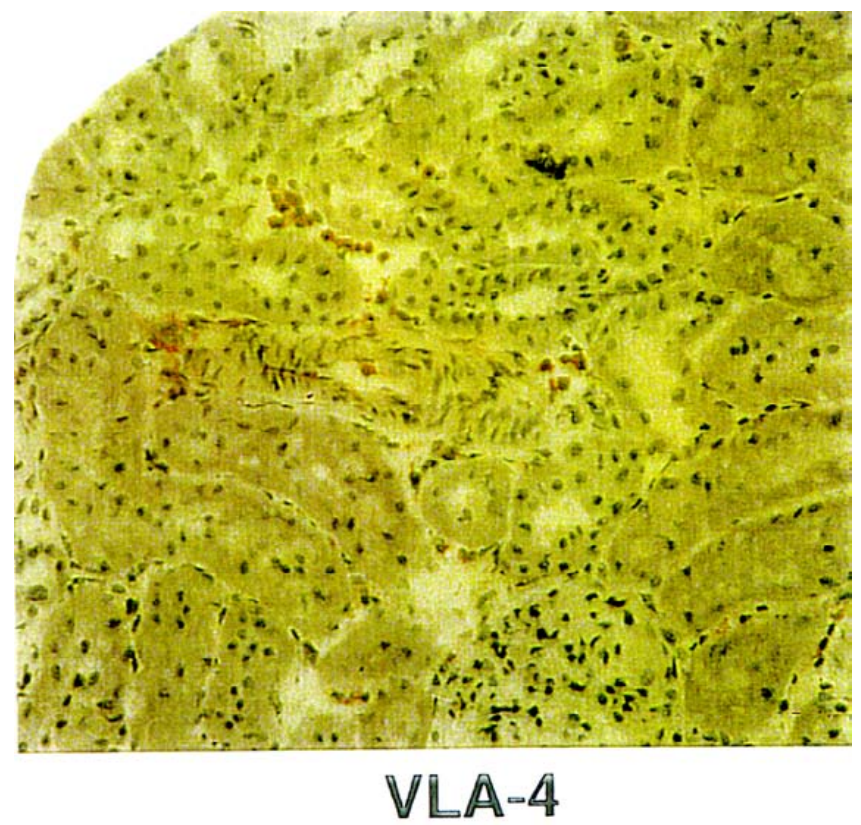

Figure 18

Representative immunohistochemical photomicrograph of VLA-4 in the kidney of SD animals.

kinases. The free NF- $\kappa \mathrm{B}$, a heterodimer consisting of 2 proteins, p50 and p65, passes into the nucleus, where it binds to $\mathrm{kB}$ sites in the promoter region of numerous genes in-

\section{TGR (human renin $\mathrm{x}$ human angiotensinogen)}

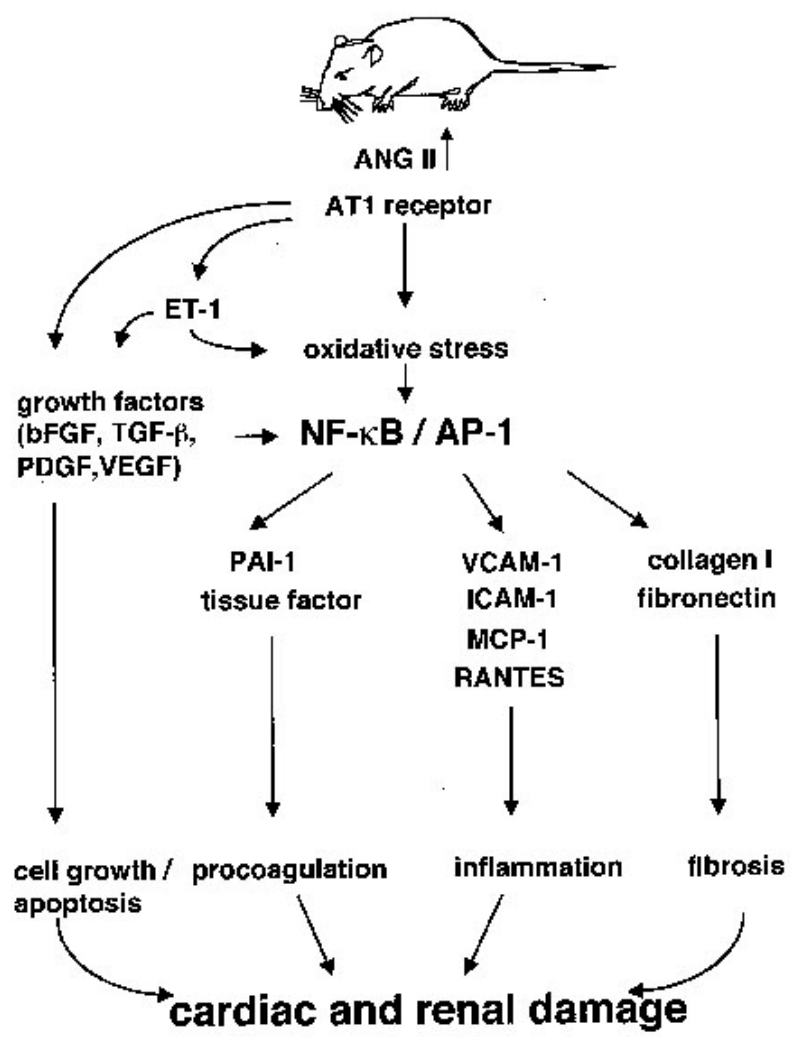

Figure 19

Schematic diagram of Ang II signaling in the dTGR model.

\section{ICAM-1 Expression in the Kidney}

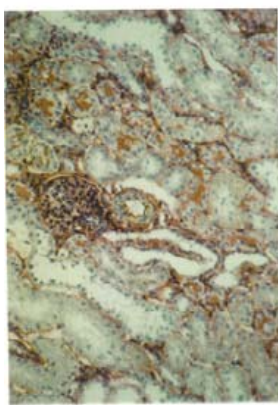

dTGR

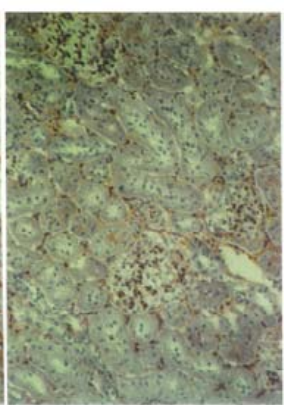

dTGR+PDTC

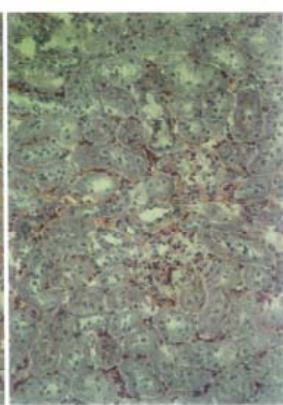

SD
Figure 20

Representative immunohistochemical photomicrographs of ICAM-I in the kidney of dTGR (a), PDTC treated dTGR (b), and SD rats (c). The expression of ICAM-I was increased in the intima, adventitia and in the perivascular space of the small dTGR vessels. Glomeruli and tubuli showed frequently increased ICAM-I expression. 


\section{iNOS Expression in the Kidney}

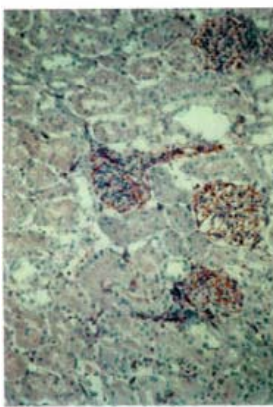

dTGR

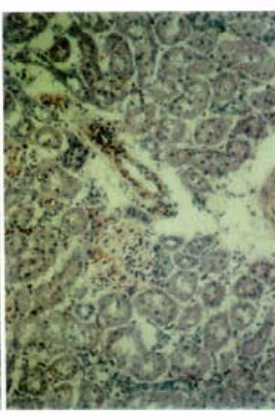

dTGR+PDTC

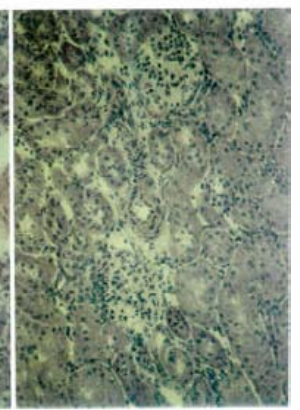

SD

Figure 21

Panel $d$-f show a representative immunohistochemical photomicrographs of iNOS in the kidney. iNOS expression was increased in glomeruli and the vessel wall of dTGR. PDTC reduced the iNOS expression.

\section{NF- $\kappa B$ subunit p65 Expression in the Heart}

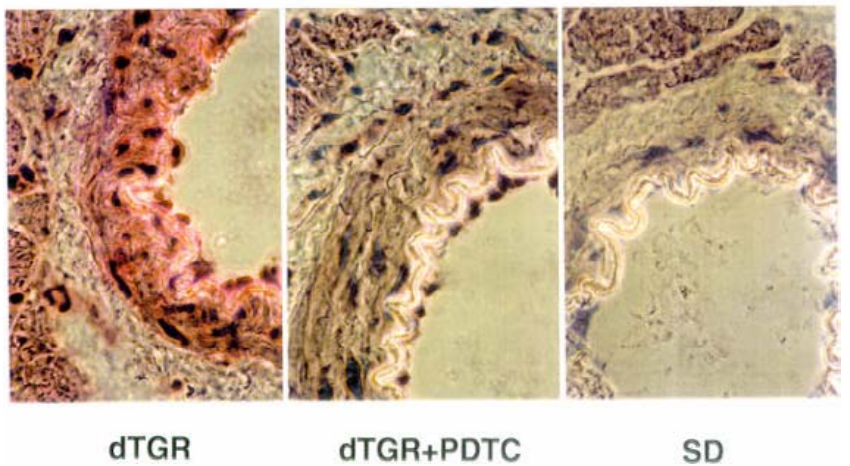

Figure 22

Immunohistochemical analysis of the subunit p65 of NF- $\kappa B$ in the heart of dTGR show a increased expression in the endothelial cells and smooth muscles cells in the vessel wall, which was partially reduced by PDTC.

volved in inflammation [29]. Many of these genes code for cytokines, chemokines, enzymes, proteins involved in coagulation, receptors, protein-ases, and adhesion molecules. These molecules contribute to the alterations in structure and mechanical properties responsible for the remodeling of resistance arteries in hypertension [30].

We tested the hypothesis that inhibition of NF-кB prevents inflammatory responses and ameliorates cardiac and renal damage. We found that NF- $\kappa \mathrm{B}$ inhibition prevented inflammatory responses, ameliorated cardiac and renal damage, and reduced mortality completely. Chronic
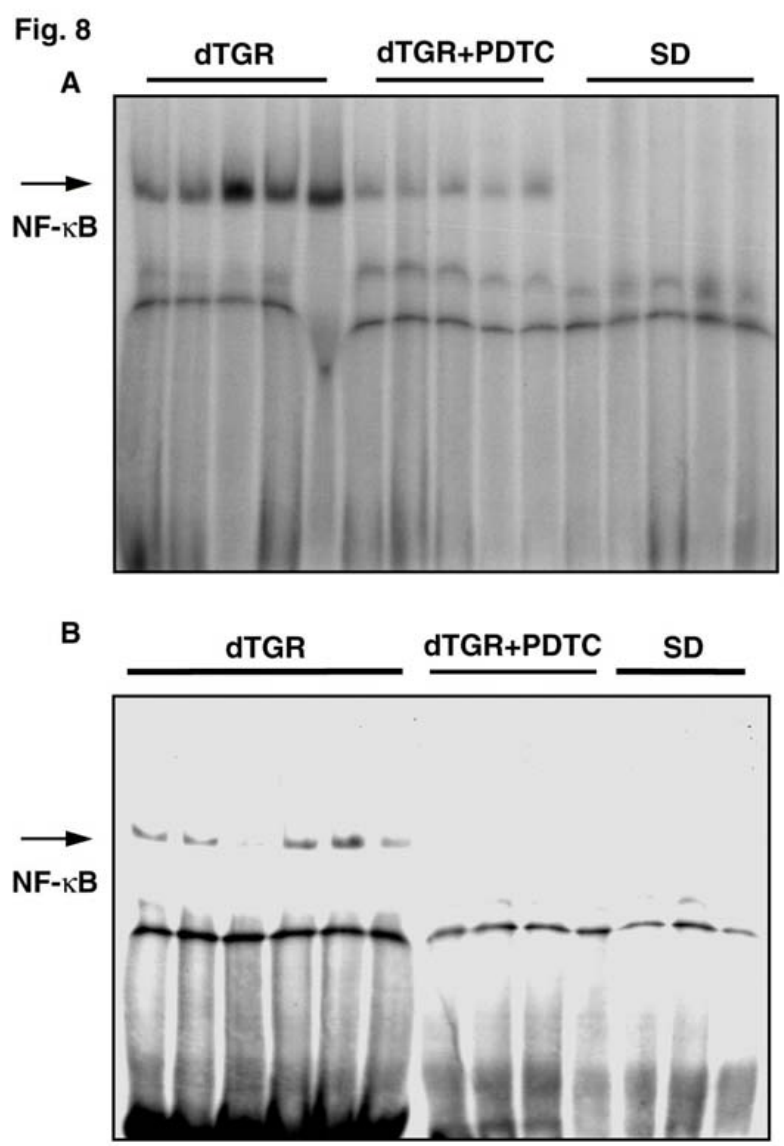

\section{Figure 23}

Effects of PDTC on the activation of DNA binding nuclear factors in the kidney (A) and heart (D). EMSA for the detection of NF-KB shows a higher binding activity of dTGR kidney and heart homogenates compared with SD rats. NF-KB DNA binding activity in the kidney was markedly reduced by PDTC treatment and even more in the heart. Each lane represents a separate animal. Renal homogenates were incubated with antibodies against the NF- $\mathrm{KB}$ subunits anti-p50, anti-p65, anti-c-Rel, and anti-Rel B (B). Specificity of binding (C) was demonstrated by competition of excess unlabeled oligonucleotides containing the $\mathrm{kB}$ site from the MHC-enhancer $(\mathrm{H} 2 \mathrm{~K})$. EMSA was performed 3 times independently with similar results.

PDTC treatment decreased blood pressure and cardiac hypertrophy slightly, but reduced albuminuria almost completely. The modest decrease in blood pressure was probably related to amelioration of renal failure rather than the result of a vasodilator effect.

We showed earlier that ANG II production in the kidneys and elsewhere is responsible for this severe vasculopathy [31]. ANG II stimulates various signaling pathways leading to NF-אB activation. PDTC is a potent inhibitor of NF- 
Fig. 9

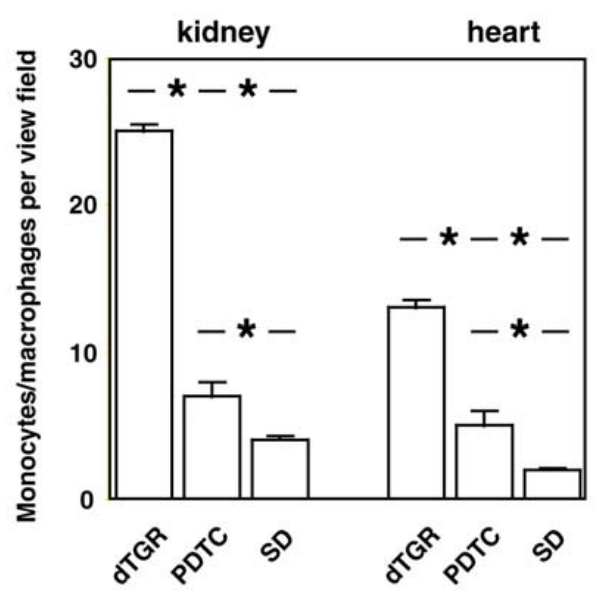

Figure 24

Semiquantative scoring for macrophage-monocyte-infiltration of ED-I in the kidney and in the heart was perforned using a computerized cell count programm.

$\kappa \mathrm{B}$ [32]. Schreck et al. and Liu et al. demonstrated that PDTC inhibited NF- $\kappa$ B activation of various stimulants, but had no effect on AP-1, CREB, Sp-1, and octamer-binding proteins in several cell lines and in vivo [14,15]. In our study, PDTC markedly decreased NF- $\kappa \mathrm{B}$ binding activity in the heart and kidney, while AP-1 was not decreased. Nakamura et al. found that administration of antioxidants inhibited cardiac hypertrophy [33]. In our model, chronic treatment with PDTC partially reduced cardiac hypertrophy.

NF- $\kappa \mathrm{B}$ plays a central role in various cardiovascular diseases. Ruiz-Ortega et al. reported that NF- $\kappa B$ activation and MCP-1 expression in the renal cortex was reduced by ACE inhibition in experimental immune complex nephritis [13]. Morrissey and Klahr showed that ACE inhibition decreased NF- $\mathrm{BB}$ in kidneys with ureteral obstruction [34]. Recently, Rangan et al. demonstrated that NF- $\kappa B$ inhibition by PDTC reduced inflammation and tubulointerstitial injury in nonimmune proteinuric rats [19]. Myocardial and renal reperfusion injury develops to a large extent subsequent to the complex interaction of multiple cytokines and activated adhesion molecules $[20,35,36]$. Morishita et al. demonstrated that NF- $\kappa B$ inhibition by a decoy technique reduced the extent of myocardial infarction following reperfusion [36]. HernandezPresa have shown that ACE inhibition prevents arterial NF- $\kappa \mathrm{B}$ activation, chemokine expression, and macrophage infiltration in early accelerated atherosclerosis [12].
We performed immunohistochemical analysis for NF- $\kappa \mathrm{B}$ subunit p65, because in contrast to the p50 subunit, p65 contains the transcription activation domain. The antibody recognizes an epitope overlapping the nuclear location signal of p65 subunit and therefore selectively stains released activated NF- $\kappa B$ after dissociation from its inhib-

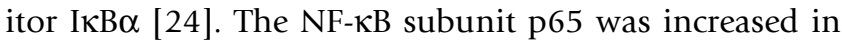
the endothelium, smooth muscles cells of damaged small vessels, and infiltrated cells in dTGR. The staining pattern resembled the localization of the p65 expression in atherosclerotic lesions.

Untreated dTGR show a 150-fold increased albuminuria. Remuzzi and coworkers demonstrated that increased glomerular permeability is followed by increased filtration of macromolecules, followed by excessive tubular protein reabsorption $[37,38]$. This process leads to abnormal accumulation of proteins in endolysosomes and endoplasmatic reticulum. Altogether, these processes foster the activation of NF- $\mathrm{KB}$ dependent and independent cytokines resulting in renal inflammation. Chronic inhibition of NF- $\kappa$ B by PDTC probably inhibited both the direct activation of NF- $\kappa$ B by ANG II as well as the subsequent activation induced by the increased glomerular permeability in our model, thereby breaking the self-amplifying loop.

We also examined inducible NO synthase (iNOS). Promoter deletion and mutation studies in cultured cells demonstrated that NF- $\kappa$ B plays a critical role in transcriptional regulation of the iNOS gene induced by various cytokines [39] NO regulates numerous physiological and pathophysiological processes, including smooth muscle contractility, platelet reactivity, and the cytotoxic activity of leukocytes. However, inappropriate release of this mediator has been linked to the pathogenesis of a number of disease states [40]. While endothelial NO serves beneficial roles as a messenger and host defense molecule, excessive NO production by inducible NOS can be cytotoxic. Indeed, peroxynitrite anion formation, protein tyrosine nitration, and hydroxyl radical production may contribute to the evolution of several commonly encountered renal diseases, including postischemic renal failure, obstructive nephropathy, and renal allograft rejection, among others [41]. Our data show that inhibition of NF- $\mathrm{KB}$ by PDTC markedly reduces inflammation, iNOS expression in the dTGR most likely leading to decreased cytotoxicity, and cell proliferation. Thus, NF- $\kappa \mathrm{B}$ activation plays an important role in ANG II-induced end-organ damage.

\section{Acknowledgments}

This study was supported by a grant-in-aid from Hoffmann-La Roche, Basel, Switzerland. Ms. Christel Lipka, Ms Mathilde Schmidt and Ms. Karin

Dressler gave expert technical assistance 


\section{References}

I. Luft FC, Mervaala E, Muller DN, Gross V, Schmidt F, Park JK, Schmitz C, Lippoldt A, Breu V, Dechend R, Dragun D, Schneider W, Ganten $D$, Haller $\mathrm{H}$ : Hypertension-induced end-organ damage : A new transgenic approach to an old problem. Hypertension 1999, 33:212-218

2. Li C, Xu Q: Mechanical stress-initiated signal transductions in vascular smooth muscle cells. Cell Signal 2000, I 2:435-445

3. Suzuki H, DeLano FA, Parks DA, Jamshidi N, Granger DN, Ishii H, Suematsu M, Zweifach BW, Schmid-Schonbein GW: Xanthine oxidase activity associated with arterial blood pressure in spontaneously hypertensive rats. Proc Natl Acad Sci U S A. 1998, 95:4754-4759

4. Griendling KK, Sorescu D, Lassegue B, Ushio-Fukai M: Modulation of protein kinase activity and gene expression by reactive oxygen species and their role in vascular physiology and pathophysiology. Arterioscler Thromb Vasc Biol. 2000, 20:2175-2183

5. Kranzhofer R, Schmidt J, Pfeiffer CA, Hagl S, Libby P, Kubler W: Angiotensin induces inflammatory activation of human vascular smooth muscle cells. Arterioscler Thromb Vasc Biol. 1999, 19:16231629

6. Berk BC, Corson MA: Angiotensin II signal transduction in vascular smooth muscle: role of tyrosine kinases. Circ Res 1997, 80:607-616

7. Muller DN, Mervaala EM, Dechend R, Fiebeler A, Park JK, Schmidt F, Theuer J, Breu V, Mackman N, Luther T, Schneider W, Gulba D, Ganten D, Haller H, Luft FC: Angiotensin II (AT(I)) receptor blockade reduces vascular tissue factor in angiotensin II-induced cardiac vasculopathy. Am J Pathol. 2000, I 57:I II-I22

8. Muller DN, Dechend R, Mervaala EM, Park JK, Schmidt F, Fiebeler A, Theuer J, Breu V, Ganten D, Haller H, Luft FC: NF-kappaB inhibition ameliorates angiotensin II-induced inflammatory damage in rats. Hypertension. 2000, 35:193-201

9. Barnes PJ, Karin M: Nuclear factor-kappaB: a pivotal transcription factor in chronic inflammatory diseases. N-Engl-J-Med. 1997, 336: 1066-107|

10. Zafari AM, Ushio-Fukai M, Akers M, Yin Q, Shah A, Harrison DG, Taylor WR, Griendling KK: Role of NADH/NADPH oxidase-derived $\mathrm{H} 2 \mathrm{O} 2$ in angiotensin II-induced vascular hypertrophy. Hypertension 1998, 32:488-495

II. Sen CK, Packer L: Antioxidant and redox regulation of gene transcription [see comments]. FASEB-J. 1996, I 0:709-720

12. Hernandez Presa MA, Bustos C, Ortego M, Tunon J, Ortega L, Egido $\mathrm{J}$ : ACE inhibitor quinapril reduces the arterial expression of NF-kappaB-dependent proinflammatory factors but not of collagen I in a rabbit model of atherosclerosis. Am-J-Pathol. 1998, I 53:1825-1837

13. Ruiz-Ortega M, Bustos C, Hernandez-Presa M, Lorenzo O, Plaza J, Edigo J: Angiotensin II participates in mononuclear cell recruitment in experimental immune complex nephritis through nuclear factor-kB activation and monocyte chemoattractant protein-I synthesis. J. Immunol. 1998, I 6 I:430-439

14. Liu S, Ye X, Malik A: Inhibition of NF-kappaB activation by pyrrolidine dithiocarbamate prevents In vivo expression of proinflammatory genes. Circulation 1999, I 00: I 330- I 337

15. Schreck R, Meier B, Mannel DN, Droge W, Baeuerle PA: Dithiocarbamates as potent inhibitors of nuclear factor kappa $B$ activation in intact cells. J-Exp-Med 1992, I 75: I I8I-I I94

16. Mervaala EM, Muller DN, Park JK, Schmidt F, Lohn M, Breu V, Dragun $D$, Ganten D, Haller H, Luft FC: Monocyte infiltration and adhesion molecules in a rat model of high human renin hypertension. Hypertension 1999, 33:389-395

17. Muller DN, Luft FC: The renin-angiotensin system in the vessel wall. Basic Res Cardiol. 1998, 93:7-I4

18. Altura BM, Gebrewold A: Pyrrolidine dithiocarbamate attenuates alcohol-induced leukocyte-endothelial cell interaction and cerebral vascular damage in rats: possible role of activation of transcription factor NF-kappaB in alcohol brain pathology. Alcohol. 1998, 16:25-28

19. Rangan GK, Wang Y, Tay YC, Harris DC: Inhibition of nuclear factor-kappaB activation reduces cortical tubulointerstitial injury in proteinuric rats. Kidney-Int 1999, 56:I I8- I 34

20. Dragun D, Tullius SG, Park JK, Maasch C, Lukitsch I, Lippoldt A, Gross V, Luft FC, Haller H: ICAM-I antisense oligodesoxynucleotides prevent reperfusion injury and enhance immediate graft function in renal transplantation. Kidney Int 1998, 54:590-602
21. Mervaala EMA, Muller DN, Park J-K, Schmidt F, Breu V, Dragun D Ganten D, Haller H, Luft FC: Monocyte infiltration and adhesion molecules in a rat model of high human renin hypertension. Hypertension 1999, 33:389-395

22. Dechend R, Homuth V, Wallukat G, Kreuzer J, Park JK, Theuer J, Juepner A, Gulba DC, Mackman N, Haller H, Luft FC: AT(I) receptor agonistic antibodies from preeclamptic patients cause vascular cells to express tissue factor. Circulation 2000, I 0 I:2382-2387

23. Dechend R, Hirano F, Lehmann K, Heissmeyer V, Ansieau S, Wulczyn FG, Scheidereit C, Leutz A: The Bcl-3 oncoprotein acts as a bridging factor between NF-kappaB/Rel and nuclear co-regulators. Oncogene 1999, 18:3316-3323

24. Zabel U, Henkel T, Silva MS, Baeuerle PA: Nuclear uptake control of NF-kappa B by MAD-3, an I kappa B protein present in the nucleus. EMBO-J. I993, I 2:201-2II

25. Luft FC: Workshop: mechanisms and cardiovascular damage in hypertension. Hypertension. 200I, 37:594-598

26. Griendling KK, Ushio-Fukai M: Reactive oxygen species as mediators of angiotensin II signaling. Regul Pept 2000, 9 I:2 I-27

27. Touyz RM, Schiffrin EL: Ang II-stimulated superoxide production is mediated via phospholipase $D$ in human vascular smooth muscle cells. Hypertension 1999, 34:976-982

28. Dechend R, Maass M, Gieffers J, Dietz R, Scheidereit C, Leutz A, Gulba DC: Chlamydia pneumoniae infection of vascular smooth muscle and endothelial cells activates NF-kappaB and induces tissue factor and PAI-I expression: a potential link to accelerated arteriosclerosis. Circulation. 1999, I 00:13691373

29. Wulczyn FG, Krappmann D, Scheidereit C: The NF-kappa B/Rel and I kappa $B$ gene families: mediators of immune response and inflammation. J Mol Med. 1996, 74:749-769

30. Siebenlist U, Franzoso G, Brown K: Structure, regulation and function of NF-kB. Ann Rev Cell Biol. 1994, I 0:405-455

31. Luft FC, Mervaala EMA, Muller DN, Gross V, Park J-K, Schmitz C, Lippoldt A, Breu V, Dragun D, Dechend R, Schneider W, Ganten D, Haller H: Hypertension-induced end-organ damage: a new transgenic approach to an old problem. Hypertension. 1999, 33:212-218

32. Munoz C, Castellanos MC, Alfranca A, Vara A, Esteban MA, Redondo JM, de Landazuri MO: Transcriptional up-regulation of intracellular adhesion molecule-I in human endothelial cells by the antioxidant pyrrolidine dithiocarbamate involves the activation of activating protein- I. J-Immunol. 1996, I 57:3587-3597

33. Nakamura K, Fushimi K, Kouchi H, Mihara K, Miyazaki M, Ohe T, Namba $M$ : Inhibitory effects of antioxidants on neonatal rat cardiac myocyte hypertrophy induced by tumor necrosis factor-alpha and angiotensin II. Circulation 1998, 98:794-799

34. Morrissey JJ, Klahr S: Rapid communication. Enalapril decreases nuclear factor kappa B activation in the kidney with ureteral obstruction. Kidney-Int. 1997, 52:926-933

35. Lenardo MJ, Baltimore D: NF-kappa B: a pleiotropic mediator of inducible and tissue-specific gene control. Cell I989, 58:227229

36. Morishita R, Sugimoto T, Aoki M, Kida I, Tomita N, Moriguchi A, Maeda K, Sawa Y, Kaneda Y, Higaki J, Ogihara T: In vivo transfection of cis element "decoy" against nuclear factor-kappaB binding site prevents myocardial infarction. Nat Med 1997, 3:894-899

37. Remuzzi G, Ruggenenti $P$, Benigni A: Understanding the nature of renal disease progression. Kidney-Int 1997, 51:2-15

38. Remuzzi G, Bertani T: Pathophysiology of progressive nephropathies. New Engl J Med. 1998, 339:I448-I456

39. Perrella MA, Patterson C, Tan L, Yet SF, Hsieh CM, Yoshizumi M, Lee ME: Suppression of interleukin-Ibeta-induced nitric-oxide synthase promoter/enhancer activity by transforming growth factor-betal in vascular smooth muscle cells. Evidence for mechanisms other than NF-kappaB. J-Biol-Chem. 1996, 27 I: | 3776-13780

40. Hobbs A, Higgs A, Moncada S: Inhibition of nitric oxide synthase as a potential therapeutic target. Annual Review Of Pharmacology And Toxicology. 1999, 39:191-200

41. Klahr S: The role of L-arginine in hypertension and nephrotoxicity. Current Opinion In Nephrology And Hypertension 1998, 7:547550 